\title{
New Microlepidoptera of the German Entomological Institute
}

\author{
by Edw. Meyrick, Marlborough.
}

\section{Pterophoridae.}

Alucita bacteriopa nov. spec. - o $15 \mathrm{~mm}$. Head and thorax whitishochreous. Forewings cleft to $2 / 5$, segments linear; whitish-ochreous; wellmarked linear black dots on costa beyond cleft and beyond middle of segment 1 , and on dorsum beyond cleft and at $1 / 3$ and $3 / 4$ of segment 2 , also a slight-dot on lower margin of segment 1 towards apex: cilia pale greyish-ochreous becoming greyer posteriorly (imperfect). Hindwings and cilia light ochreous-grey.

Amani; 1 ex. (coll. Morstatt).

\section{Gelechiadae.}

Onebala cyclopodes nov. spec. - ô $14 \mathrm{~mm}$. Head and thorax dark purplish-fuscous, face pale ochreous. Antennae serrate with whorls of scales, pale ochreous, ciliations 1. Palpi pale ochreous, second joint dark fuscous except apex. Forewings elongate, costa gently arched, apex obtuse, termen faintly sinuate, rather oblique; 2 and 3 stalked, 4 absent, 7 absent, 8 and 9 stalked; dark purplish-fuscous; a large rounded-transverse pale ochreous spot on costa at $3 / 4$ : cilia dark grey (imperfect). Hindwings dark grey; cilia grey.

Amani; 1 ex. (coll. Morstatt) not in good condition, but appears distinct.

Onebala bifrenata Meyr. - Amani; 2 examples (coll. Morstatt), which I regard as belonging to this species, described from a $\hat{o}$ only, have the hindwings darker grey, and vein 10 of the forewings present, posterior line of forewings very slender, crown of head more broadly purplish-grey, but these differences seem likely to be only sexual.

Timyra temenodes nov. spec. - o $23-25 \mathrm{~mm}$. Head and thorax grey. Palpi grey, second joint broadly dilated with scales, suffused whitish beneath, and enveloped in long whitish expansible hairs projecting above, terminal joint shorter, much thickened with dense scales throughout. Antennae with large dense tuft of grey scales from basal joint in front. Posterior tibiae above with long erect spreading loosely curled whitish hairscales, at apex of joint suffused ochreousyellow. Forewings elongate, costa slightly arched, apex obtuse, termen slightly rounded, somewhat oblique; grey, irregularly speckled with whitish, costal edge pale yellowish; a narrow transverse ochreouswhitish fascia towards base not reaching costa: cilia pale yellowish, 
suffused grey towards tornus. Hindwings light ochreous-yellow; an irregular dark grey marginal band running all round wing except in middle of base; cilia light yellowish, a grey subbasal shade.

Ceylon; 1 ex. (coll. Dr. W. Horn, 1899): also 1 in my collection from Maskeliya, Ceylon.

\section{Xyloryctidae.}

Odites armilligera nov. spec. - $\hat{\jmath}$ ㅇ. $11-12 \mathrm{~mm}$. Head and thorax pale ochreous. Palpi whitish, second joint suffused with dark fuscous except apex, terminal joint with base and two bands dark fuscous. Antennae of $\hat{\sigma}$ minutely ciliated. Forewings elongate, costa gently arched, apex tolerably pointed, termen slightly rounded, rather strongly oblique; pale ochreous, irregularly sprinkled with fuscous and dark fuscous; discal stigmata rather large, black; an almost marginal series of rather large blackish dots round posterior part of costa and termen to before tornus: cilia pale ochreous. Hindwings and cilia ochreous whitish.

Amani; 4 ex. (coll. Morstatt). The banded terminal joint of palpi is characteristic.

Caenorycta nov. gen. - Head with appressed scales, sidetufts dense, raised; ocelli inferior; tongue apparently rudimentary. Antennae $3 / 4$, in $\hat{o}$ subdentate, strongly ciliated, basal joint stout, sub concave beneath, without pecten. Labial palpi very long, recurved, second joint exceeding base of antennae, thickened with dense scales and slightly rough beneath, terminal joint shorter, moderate, pointed. Maxillary palpi rudimentary. Posterior tibiae clothed with hairs above. Forewings $1 \mathrm{~b}$ furcate, 2 from $3 / 5,3$ from near angle, 4 and 5 connate from angle, 7 and 8 stalked, 7 to termen, 11 from middle. Hindwings over 1 , trapezoidal-ovate, cilia $1 / 4 ; 3$ and 4 connate, 5 nearly parallel, 6 and 7 short-stalked.

Caenorycta dryoxantha nov. spec. - o $38 \mathrm{~mm}$. Head whitishochreous, sides of erown brownish. Palpi pale ochreous, second joint with a dark brown lateral streak on basal half, terminal joint infuscated posteriorly. Antennal ciliations 2. Thorax whitish-ochreous, posterior half suffused brownish. Abdomen pale ochreous, segmental margins deep fulvous, segment 2 with deep fulvous dorsal blotch. Forewings elongate, posteriorly dilated, costa gently arched, apex obtuse, termen rounded, somewhat oblique; pale ochreous, with scattered dark brown scales; a dark brown dot near base in middle; an elongate brown patch sprinkled with dark fuscous extending along dorsum from $1 / 5$ to $4 / 5$, pointed anteriorly, reaching $1 / 3$ across wing and truncate posteriorly, upper edge with an obtuse prominence suffused with dark fuscous. 
before middle; an indistinct median line of dark brown suffusion from near base to termen; second discal stigma linear, dark fuscous; some brownish tinge on tornal area; a dark fuscous mark on costa at $3 / 4$ : cilia pale ochreous, a subbasal shade of dark fuscous suffusion interrupted into spots, tips suffused fuscous (imperfect). Hindwings ochreousyellow; cilia yellowish suffused brownish-purple (imperfect).

British New Guinea, Biagi, Mambave R. (coll. A. S. Meek, I-IV, 1906, 5000 feet), 1 ex.

\section{Copromorphidae.}

Endothamna nov. gen. - Head with appressed scales, sidetufts loosely raised; ocelli posterior; tongue developed. Antennae 4/5, basal joint moderate, without pecten. Labial palpi very long, porrected, second joint very long, with dense rough projecting scales on apical $2 / 3$ above and round apex, beneath with appressed scales becoming rough near apex, terminal joint less than half second, very obliquely subascending, thickened with scales roughly projecting anteriorly above middle, pointed. Maxillary palpi obsolete. (Posterior legs missing.) Forewingswith dorsal scale-projection near base and very large apparently expansible longitudinal fringe-tuft of long rough scales in middle of disc directed downwards; 2 from angle, 2-5 approximated at base, 7 to costa, $7-9$ nearly approximated at base, 11 from middle. Hindwings 1 , trapezoidal-ovate, cilia $1 / 3$; no cubital pecten; $2-4$ nearly parallel, 4 and 5 connate from angle of cell, 6 and 7 nearly parallel.

A singular form, differing from all others of the family in costal termination of 7 of forewings, and connate 4 and 5 of hindwings, besides the curious discal fringe.

Endothamna marmarocyma nov. spec. - $+21 \mathrm{~mm}$. Head greywhitish somewhat mixed with brown. Palpi whitish sprinkled with dark fuscous, terminal joint dark fuscous except base. Thorax grey-whitish irregularly mixed with dark fuscous. Forewings suboblong, costa anteriorly moderately, posteriorly slightly arched, apex obtuse-pointed, termen slightly rounded, rather oblique; whitish, slightly speckled with fuscous, strewn with transverse bright silvery strigulae edged posteriorly with blackish; markings dark pinkish-grey; a slender costal streak from base terminated by a spot at $1 / 4$; a large patch occupying dorsal $3 / 5$ from near base to near tornus, the large discal fringe-tuft of long whitish scales dotted with dark grey projecting downwards across this, its apex nearly reaching dorsum in middle; a suffused blotch on middle of costa; an oblique streak from costa at $3 / 5$ reaching half across wing; a thicker streak near and parallel to termen, not reaching costa, beneath running to lower angle of dorsal patch; a 
small spot on costa at $4 / 5$ : cilia whitish, a dark fuscous basal line and fuscous median shade. Hindwings pale purplish-grey; cilia whitish, a faint grey subbasal line.

Chile, Concepcion (coll. Herbst, 21. I. 1906), 1 ex. A remarkable insect of unusual aspect.

\section{Glyphipterygidae.}

Heliostibes percnopa nov. spec. - o $16 \mathrm{~mm}$. Head and thorax dark fuscous somewhat sprinkled with whitish. Palpi dark fuscous, second joint tinged orange interiorly, terminal joint whitish interiorly. Antennal ciliations 21/2. Forewings elongate-triangular, costa gently arched, apex obtuse, termen rounded, rather oblique; dark fuscous, suffusedly mixed with ferruginous on posterior half: cilia dark fuscous, sprinkled with ferruginous. Hindwings bronzy-blackish; cilia dark fuscous.

Chile, Concepcion (coll. Herbst, 17. XII. 1908), 1 ex. The second Chilean species of this interesting genus, which is confined to Chile and New Zealand.

\section{Hyponomeutidae.}

Homadaula anisocentra nov. spec. - $+15 \mathrm{~mm}$. Head, palpi, and thorax grey, slightly and minutely speckled with whitish. Forewings elongate, costa gently arched, apex obtuse, termen obliquely rounded; glossy grey; about 30 irregularly placed black dots in disc, varying in size from moderate to minute, the largest representing second discal stigma, and five others minute on termen: cilia grey. Hindwings grey veins and termen suffused dark grey; cilia whitish-grey, with grey subbasal shade.

China, Tsingtau (coll. Prof. Hoffmann), 1 ex. The genus Homadaula has only been recorded previously from Australia, where there are several species.

\section{Die paläarktischen Tenebrioniden des Deutschen Entomologischen Institutes. NNo. II (Col.).}

Von Adrian Schuster (Wien IV).

18. Pimelia simulatrix $\mathrm{Kr}$.

P. simulatrix Kr. ist, nach der Type, eine Stalagmoptera und wahrscheinlich mit St. pterocomoides Rtt. synonym.

18. Pimelia echidna Fairm. und var. oblonga Sénac.

Sénac hat Recht, wenn er in seiner ausgezeichneten Monographie II, p. 11 die Vermutung ausspricht, daß oblonga eine eigene Art sei. P. echidna hat einen granulierten Kopf, der Halsschild ist an den 


\section{$2 \mathrm{BHL}$ Biodiversity Heritage Library}

1922. "New Microlepidoptera of the German Entomological Institute." Entomologische Mitteilungen 11, 44-47. https://doi.org/10.5962/bhl.part.3332.

View This Item Online: https://www.biodiversitylibrary.org/item/39843

DOI: https://doi.org/10.5962/bhl.part.3332

Permalink: https://www.biodiversitylibrary.org/partpdf/3332

\section{Holding Institution}

Smithsonian Libraries

\section{Sponsored by}

Smithsonian

\section{Copyright \& Reuse}

Copyright Status: NOT_IN_COPYRIGHT

This document was created from content at the Biodiversity Heritage Library, the world's largest open access digital library for biodiversity literature and archives. Visit BHL at https://www.biodiversitylibrary.org. 